DOI https://doi.org/10.36059/978-966-397-116-2/172-193

\title{
MUTUAL INSURANCE COMPANIES AS PARTICIPANTS OF CONTRACTUAL INSURANCE RELATIONS
}

\section{Milovska N. V.}

Insurance contractual relations as well as any civil legal relations are revealed through a set of their elements, namely, subjects, objects and content. One of the most essential issues is the determination of peculiarities of subject composition of the relations mentioned. Thus, in Chapter 67 of the Civil Code of Ukraine (hereinafter - the CC of Ukraine), dedicated to insurance contracts, as well as in other chapters related to contracts, the main content of articles is reduced to determination of someone who concludes and how someone concludes the contract, what rights and obligations of the parties are, which legal consequences will arise due to violation of contract terms and conditions. Therefore, the most norms in the field of contractual relations are dedicated to the parties of legal relations such as counterparties to the contract.

Legislative approaches to determination of the circle of possible participants in legal relations and determination of their legal status are reduced today to the method of self-regulation of contractual civil relations by their participants directly ${ }^{1}$. Thus, the legal conditions of the parties to the contract are determined by legal relations participants themselves taking into account basic provision in civil law acts.

As it follows from Articles 979, 984 of the Civil Code of Ukraine and provisions of Article 16 of the Law of Ukraine "On Insurance", the parties to the insurance contract are the insurer and the insured. The insurer and the insured are the main participants of insurance relations since they take part in their emergence, change and termination directly. The participation of all other participants depends on the will of the insured party andlor the insurer exactly, as well as it is resulted from Ukrainian current legislation provisions.

\footnotetext{
${ }^{1}$ Погрібний С. О. Механізм та принципи регулювання договірних відносин у цивільному праві України: монографія. К.: Правова єдність, 2009. С. 4.

2 Закон України «Про страхування» від 7 березня 1996 р. // Відомості Верховної Ради України. 1996. № 18. Ст. 78.
} 
The Civil Code of Ukraine defines the insurer as a legal entity specially created for carrying out insurance activity and has received a license for the insurance activity under the established procedure (Part 1, Article 984). At the same time, as it follows from Article 979 of the Civil Code, the insurer is a party to an insurance contract, undertaking an obligation to make an insurance payment upon the occurrence of an insured event.

Based on requirements of the Law of Ukraine "On Financial Services and State Regulation of Markets of Financial Services"3, as well as the Law of Ukraine "On Insurance", financial services in general and insurance services in particular should be provided directly by the person to whom such right is provided not by a contract, but by law, taking into account its requirements. In this regard insurance can be carried out exclusively by financial institutions, stipulated by Article 2 of the Law of Ukraine "On Insurance", which have received a license for the right to carry out insurance activities. Thus, according to Article 2 of the Law of Ukraine "On Insurance", financial institutions are recognized as insurers created in the form of joint-stock companies, full, limited partnerships or companies with additional liability and carry out insurance activities based on relevant license. Enterprises, institutions and organizations can not become insurers by amending the statutory documents, provided that they were previously engaged in another type of activity.

In addition to commercial insurance organizations, the subjects of insurance relations are mutual insurance companies. Thus, natural persons and legal entities for the purpose of insurance protection of their property interests may create mutual insurance companies (Article 14 of the Law of Ukraine "On Insurance"), not aimed at obtaining profit, and therefore, they are not subjects of entrepreneurial activity. This is the main difference between a mutual insurance company and a commercial insurance organization, for which the provision of insurance protection is a means of obtaining profit ${ }^{4}$. As scientific literature notes, mutual insurance as a separate type of insurance, other than direct insurance, coinsurance and reinsurance, is a non-commercial form of insurance

\footnotetext{
3 Закон України «Про фінансові послуги та державне регулювання ринків фінансових послуг» від 12 липня 2001 р. // Відомості Верховної Ради України. 2002. № 1. Ст. 1.

${ }^{4}$ Адамов А. С. Історичні аспекти взаємного страхування // Актуальні проблеми держави і права. 2009. Вип. 51. С. 253.
} 
protection based on a group agreement on reimbursement in certain amounts of damages to each other in case of occurrence of insured events 5 . The main goal of mutual insurance consists in redistribution of risks, providing its participants with the most qualitative, diverse insurance services at a reasonable price. According to experts' evaluations, mutual insurance companies play an important role at the insurance markets of most developed countries ${ }^{6}$. Six out of ten biggest insurance companies in the world are mutual insurance companies ${ }^{7}$.

The legal principles of a mutual insurance company activity in Ukraine are currently limited to Article 14 of the Law of Ukraine "On Insurance", Part 3 of Article 352 of the Commercial Code of Ukraine and the Provisional Regulations on the Mutual Insurance Company, approved by the Resolution of the Cabinet of Ministers of Ukraine on February 1, $1997^{8}$. Thus, Article 14 of the Law of Ukraine "On Insurance" and Part 3 of Article 352 of the Commercial Code of Ukraine only declare the possibility of establishing mutual insurance companies and include a reference to another legal act, namely, the Provisional Regulations, where at the same time it is not defined the following: the concept of mutual insurance, objects of mutual insurance, the grounds for becoming a member of a mutual insurance company, the procedure for withdrawal and the procedure for the exclusion of members from a mutual insurance company, the grounds for obtaining a license by a mutual insurance company, etc. ${ }^{9}$

Thus, the legal framework, which has to regulate the activities of mutual insurance companies in Ukraine, is now almost absent leading to the winding up of previously established companies. So, in Ukraine today, not any mutual insurance company, which carries out non-profit

\footnotetext{
${ }^{5}$ Економічний зміст і принципи організації взаємного страхування. ${ }^{\text {URL: }}$ http://uig.com.ua/index.php? option=com_content\&task (дата звернення: 26.12.2018); Абрамов В. Ю. Общества взаимного страхования. Особенности правового положения // Страховое право. 2005. № 2. С. 4-7; Гришин Г. В. Общества взаимного страхования // Страховое право. 2000. № 4. С. 47-51; Логвинова И. Л. Взаимное страхование как метод создания страховых продуктов. М.: Анкил, 2010. С. 66.

${ }^{6}$ Адамов А. С. Історичні аспекти взаємного страхування // Актуальні проблеми держави і права. 2009. Вип. 51. С. 254.

${ }^{7}$ Економічний зміст і принципи організації взаємного страхування. URL: http://uig.com.ua/index.php? option= com_content\&task (дата звернення: 26.12.2018)

${ }^{8}$ Тимчасове положення про товариство взаємного страхування, затверджене постановою Кабінету Міністрів України від 1 лютого 1997 p. URL: http://zakon2.rada.gov.ua/laws/show/132-97-\%D0\%BF (дата звернення: 27.12.2018).

${ }^{9}$ Мачуський В. В. Взаємне страхування: організаційно-правові аспекти // Право України. 2008. № 4. C. 64 .
} 
insurance, is registered. And this negatively affects the realization of the insurance institution potential and points to the structural imbalance of the national insurance market ${ }^{10}$. Attempts for their creation were made during 1995-1998, when the following mutual insurance companies were officially registered: "Nasha Sprava" and "Ukrmistsevprom», organized by enterprises of local industry; "Kyiv Regional Fund for Mutual Insurance "Promyslova Ukraina"11. The termination of the legal framework further development for the functioning of mutual insurance companies led to uncertainty in their legal status that forced the abovementioned mutual insurance companies to terminate their activities.

At the same time, there is no comprehensive research in the field of mutual insurance in scientific literature. Some aspects of the issue mentioned are reflected in the works of P. A. Strelbitsky ${ }^{12}$, A. A. Panteleymonenko ${ }^{13}$, S. A. Navrotsky ${ }^{14}$. The historical-legal aspect of mutual insurance organizations was considered by A. S. Adamov ${ }^{15}$, V. V. Machusky ${ }^{16}$, and K. M. Tverdomed ${ }^{17}$. However, the area of mutual insurance is the subject of research mainly by economists-scientists, whose works in the context of the very legal regulation of mutual insurance are of a general review nature.

In general, a mutual insurance company is a legal entity, an insurer created to insure the risks of its members, whose rights and obligations are determined by the fact that each participant is both an insurer and the insured at the same time. In foreign publications, the mutual insurance company (in German - Gesellschaft zur gegenseitigen Versicherung) is regarded as non-commercial insurance organization which has no aim to

10 Віленчук О. М. Еволюція становлення та розвитку некомерційного страхування в аграрній сфері // Вісник ЖНАЕУ. 2012. № 1(2). С. 98.

11 Манжура О. В. Кооперативи у страховому секторі: історичний досвід і перспективи для України // Вісник аграрної науки Причорномор'я. 2015. Вип. 1. С. 79.

12 Стрельбіцький П. А. Товариства взаємного страхування: зародження, розвиток, становлення // Вісник Хмельницького інституту регіонального управління та права. 2003. № 2 (6). С. 264-271.

13 Пантелеймоненко А. О. Західноєвропейські товариства взаємного страхування та страхові кооперативи: сутність організації, зміст діяльності i значення. URL: http://www.ukrcoopjournal.com.ua/num/ pantelejmonenko1.htm (дата звернення: 27.12.2018).

${ }^{14}$ Навроцький С. А. Розвиток товариств взаємного страхування в АПК // Вісник Тернопільської академії народного господарства. 2001. Вип. 15. С. 63-65.

15 Адамов А. С. Історичні аспекти взаємного страхування // Актуальні проблеми держави і права. 2009. Вип. 51.

${ }_{16}$ Мачуський В. В. Правове регулювання страхової діяльності в Україні (господарсько-правові аспекти): автореф. дис. на здобуття наук. ступеня канд. юрид. наук: спец. 12.00.04. К., 2013. 15 с.

17 Твердомед К. Кооперативне страхування в Україні в період непу (1921-1929) // Право України. 2003. № 2. С. 135-139. 
obtain profit and is designed to provide insurance services at the lowest possible cost in favor of its members ${ }^{18}$.

The decision on the amount and terms of insurance contribution payment of each individual member of the company is determined in accordance with the procedure established by the supervising body of the mutual insurance company depending on financial conditions of each company's member in accordance with the conditions specified in the contract concluded between the members and the mutual insurance company. Each member of the company, in case of fulfillment of all their obligations to the mutual insurance company, regardless of the amount of insurance contribution, has the right to receive necessary insurance indemnity in full in case of an insured event occurrence (Clause 5 of the Provisional Regulations).

Insurance relations between the above company and its members are based on the concluded insurance contract in which the subject of insurance, insurance amounts, the procedure for their payment and the procedure for making insurance payments are determined taking into account the peculiarities of each company's member ${ }^{19}$. Moreover, the responsibilities of one company's member may be assigned to another one, that is, the insurance contract may provide payments of one or more members of the company for other members in full or in part. In case of one insurer's withdrawal from the company or its winding up, the contract between its other members remains in force. Company's members receive a certificate confirming their accession to the insurance contract, the procedure for issuing of which is established by the National Commission for the Regulation of Markets of Financial Services (Clause 6 of the Provisional Regulations).

As a rule, mutual insurance companies do not use the services of insurance intermediaries and all operations are carried out at the expense of the company's insurance funds; and in case of shortage of funds, its members make additional contributions according to the decision of the general meeting.

\footnotetext{
18 Definition of «Mutual Company». URL: http://www.investopedia.com/ terms/m/mutualcompany.asp (Last accessed: 27.12.2018).

19 Страховое право: учебник / Под. ред. В. В. Шахова, В. Н. Григорьева, А. П. Архипова. М.: ЮНИТИ-ДАНА: Закон и право, 2008. С. 179.
} 
Under the conditions of European integration processes taking place in Ukraine, the European experience of legal regulation of noncommercial forms of insurance protection is of great importance. Thus, the operation of mutual insurance companies is regulated by the European Commission Directives, according to which, licenses are not required for mutual insurance companies, in particular, if their activities are of local nature and the annual amount of insurance premiums collected does not exceed 5 million Euro $^{20}$. However, under the legislation of Ukraine, when carrying out insurance activities without a license, a mutual insurance company can not be considered an insurer, since according to Article 2 of the Law of Ukraine "On Insurance" only legal entities in any organizational-legal form that have received a license to carry out insurance activities are recognized as insurers.

Therefore, in contractual insurance relations only the legal entity, which is given the opportunity to carry out its insurance activity only after obtaining a special permit (license), can be on the insurer's part, indicating the presence of special legal capacity in legal entities insurers. Moreover, a special legal capacity determines the presence not only the status of a legal entity in insurance organizations, but also the status of a financial institution, in accordance with Article 2 of the Law of Ukraine "On Financial Services and State Regulation of Markets of Financial Services".

Licensing of insurance organizations is carried out in accordance with the Law of Ukraine "On Licensing of Economic Activity Types"21 and the Resolution of the Cabinet of Ministers of Ukraine "On Approval of Licensing Conditions for the Provision of Financial Services (except for professional activities at the securities market) ${ }^{322}$ and is necessary to verify the compliance of the legal entity, its assets and founders to requirements for subjects of insurance.

Part 2 of Article 38 of the Law of Ukraine "On Insurance" stipulates a clear division of insurers into those who have received a license for life

\footnotetext{
20 Заєць О. М. Реформування інституту страхування України з урахуванням положень угоди про асоціацію з Свропейським Союзом // Правова реформа в сучасних умовах: досягнення і перспективи: VI Міжнар. наук-практ. конф. 26 лютого 2016 р. Т. ІІ. К.: Нац. авіац. ун-т, 2016. С. 265.

21 Закон України «Про ліцензування видів господарської діяльності» від 2 березня 2015 p. № 222-VIII // Відомості Верховної Ради України. 2015. № 23. Ст. 158.

22 Ліцензійні умови провадження господарської діяльності 3 надання фінансових послуг (крім професійної діяльності на ринку цінних паперів), затверджені постановою Кабінету Міністрів України від 7 грудня 2016 р. № 913. URL: http://zakon.rada.gov.ua/laws/show/913-2016-\%D0\%BF (дата звернення: 25.12.2018).
} 
insurance and those engaged in other types of insurance. The combination of these types of insurance is prohibited by law. It is worth noting that such a division of insurance organizations corresponds to international experience and indicates their clear specialization in the division of insurers for "Life insurance" and "Non-life" or "General insurance" 23 . At the same time V. M. Nikiforak points out that, unlike property and personal insurance, some types of which require a special license, one general license is issued for all types of liability insurance. The exception is civil liability insurance of a nuclear installation operator because an insurance company must obtain an individual license to carry out such insurance ${ }^{24}$.

So, the types of insurance, which an insurer has the right to carry out, are indicated in the license. In accordance with clause 5 of Article 1 of the Law of Ukraine "On Licensing of Economic Activity Types", a license is a record in the Unified State Register of Legal Entities, Natural PersonsEntrepreneurs and Public Formations about the decision of a licensing authority regarding the existence of the business subject's right to carry out a type of economic activity subject to licensing. Issuance of licenses to insurers for carrying out insurance activity and carrying out of inspections for their compliance with the issued license according to Article 36 of the Law of Ukraine "On Insurance" is carried out by the authorized body, which is the National Commission, carrying out state regulation in the field of markets of financial services.

Licensing of mutual insurance companies is determined by the state task of preventing the emergence of unfair insurers at the insurance market and ensuring protection of the insured parties' interests ${ }^{25}$. At the same time, some researchers consider licensing, the main meaning of which is to control the activities of insurers, as an inappropriate form for non-profit insurance companies which fund is formed on the basis of participants' contributions, and the activity is based on principles of joint responsibility of members for its results and carried out on a nonprofit basis $^{26}$.

\footnotetext{
${ }^{23}$ Страхування: навч. посіб. / Т. А. Говорушко, В. М. Стецюк; за ред. Т. А. Говорушко. К., Львів: «Магнолія 2006», 2014. С. 30-31.

${ }^{24}$ Никифорак В. М. Договір страхування відповідальності: автореф. дис. ... канд. юрид. наук: 12.00.03; НАН України, Інститут держави і права ім. В. М. Корецького. К., 2002. С. 7.

${ }_{25}$ Міловська Н. В. Корпоративні відносини у сфері взаємного страхування // Право і суспільство. 2017. № 5-2. С. 84.

${ }^{26}$ Дадьков В. Н. Взаимное страхование / В. Н. Дадьков, К. Е. Турбина. М.: Анкил, 2007. С. 55.
} 
In order to ensure the insurer's solvency and executions of obligations against the insured parties, significant restrictions are imposed on the subject of the insurer's activities, types of insurance, the minimum amount of authorized capital, etc. So, the insurance activity in Ukraine is carried out, with minor exceptions, by insurers - residents of Ukraine having not less than three participants in its composition. The subject of insurer's activity may be insurance, reinsurance and financial activities related to the formation, allocation and management of insurance reserves only. These activities are allowed to be performed in the form of service provision to other insurers on the basis of concluded civil law contracts, if this is directly related to the specified types of activity, as well as any operations for the provision of own economic needs (Article 2 of the Law of Ukraine "On Insurance"). In turn, insurers, carrying out life insurance according to Article 2 of the Law of Ukraine "On Insurance" can provide loans to the insured who have concluded life insurance contracts. The procedure, terms of issue and the amount of loans as well as the procedure for forming a reserve for covering possible losses is established by the Authorized body with the approval of the National Bank of Ukraine. According to Article 30 of the Law of Ukraine "On Insurance", the minimum amount of insurer's statutory fund (guarantee deposit) carrying out insurance activities other than life insurance is set in the amount equivalent to 1 million Euro, and for the insurer who carries out life insurance - 10 million Euro according to the currency exchange rate of Ukraine.

Compulsory insurance can be carried out by the insurer only on condition that the procedure and rules for its performance determined by the Cabinet of Ministers of Ukraine are followed as well as a standard form of the contract, special conditions of licensing, the amount of insurance sums, maximum rates of insurance tariffs or the methodology of actuarial settlements, if otherwise is not specified by law (clause 49 Licensing conditions for conducting economic activities for the provision of financial services (except for professional activities at the securities market). So, if a certain type of insurance is attributed by the Law of Ukraine "On Insurance" to the compulsory one, then in accordance with Clause 12 of the Licensing Conditions for conducting economic activities for the provision of financial services (except for professional activities at the securities market), the insurer (applicant of the license) on the date of 
document submission for obtaining a license should carry out insurance activity on the insurance contract conclusion in each reporting quarter, not less than two years (eight reporting quarters). In turn, in order to obtain a license for compulsory insurance of civil law liability of owners of motor transport vehicles, the insurer (license applicant) must additionally have experience in settling insurance claims and payment of insurance indemnity for at least ten such contracts.

Therefore, the general requirements for insurers carrying out insurance, are as follows: a) the creation of an insurer only in a definite organizational legal form (joint stock, full, limited company or a additional liability company); b) there must be at least three participants of the insurer; c) possession of a license for insurance; d) observance of requirements regarding the amount and procedure of the authorized capital formation; e) exceptional nature of the insurer's activities (insurance, reinsurance and financial activities related to the formation, allocation and management of insurance reserves); e) inclusion in the list of financial institutions in accordance with the Law of Ukraine "On Financial Services and State Regulation of Markets of Financial Services Markets"; e) the experience in the insurance activity conduct with the conclusion of insurance contracts with the aim of carrying out compulsory insurance. At the same time, as a party to the insurance contract, the insurer is a legal entity, being specially created for the provision of insurance services and having received a license in accordance with the established procedure, undertakes to fulfill obligations, in accordance with the terms and conditions of the contract or orders of the law, to make an insurance payment (insurance indemnity) to the insured or beneficiary as a result of the occurrence of a particular event (insured event). Since the moment of state registration of an insurance organization and the issuance of a license for the right to provide certain types of insurance, the insurer is legally capable and able to do so. The insurance organization has a general legal capacity of a legal entity with a special scope pf capacity as a financial institution, since it is the obtaining of a license that enables them to carry out insurance activities, that is, to acquire rights and bear responsibilities in the process of insurance by their actions.

Obligations on insurance in mutual insurance companies arise from corporate relations, namely, relations of membership (participation in a company). Therefore, only its participants (members) can use services of 
the company in insurance of certain interests. Corporate interest is the basis of building a membership in the company.

The object of corporate legal relations is an actual behavior of a corporate law holder in the exercise of their rights and obligations. Therefore, corporate legal relations contain elements of both property (payment of insurance payments) and non-property relations (participation in the activities of general meeting, its other bodies in the case of election to them), the parties construct them on the principles of legal equality of parties, based on the requirements of civil law and local acts. Such relations do not have the nature of power and subordination and therefore are not administrative-legal ones.

The rights and obligations of members of non-profit insurance organizations are determined by the specifics of the latter, where each participant is the insured and the insurer at the same time. The connection between the participants' rights and obligations is reflected in the part of implementation of insurance relations. This feature determines the specifics of their obligations: all participants jointly act as the guarantor of the insurance indemnity payment to each insured and, in the case of lack of funds they cover damage by paying additional contributions.

The general rights and obligations of the parties to the insurance contract are provided for by the Civil Code (Articles 988, 989) and the Law of Ukraine "On Insurance" (Articles 20, 21). Thus, according to the current legislation, the insurer under the insurance contract is obligated: to familiarize the insured with the conditions and rules of insurance; within two working days, as soon as it becomes known about occurrence of an insured event, to take measures for execution of all necessary documents for timely payment of insurance payment (insurance indemnity) to the insured; upon occurrence of an insured event, to make an insurance payment (indemnity) in the period stipulated by the contract. The insurer bears property responsibility for non-timely insurance payment (indemnity) by paying a penalty (fine) to the insured, the amount of which is determined by insurance contract conditions; to compensate the expenses incurred by the insured at the occurrence of an insured event in order to prevent or reduce losses, if it is provided by terms and conditions of the contract; upon the request of the insured in case when the insured carries out measures that reduce the insurance risk, or in case of an increase in property value, to renew the insurance contract; not to disclose 
confidential information about the insured and their property status, except in cases stipulated by the legislation of Ukraine. The insurance contract can stipulate other insurer's obligations as well.

Therefore, the insurer's primary obligation when concluding an insurance contract is to familiarize the insured with the conditions and rules of insurance. If the insurer and the insured have concluded an insurance contract, the further reference of the latter to the fact that they were not familiar with the relevant rules, should not be taken into account as a rule ${ }^{27}$. However, as Yu. A. Kulina notes, only the record about receiving of insurance rules by the insured is a valid proof that the insurer fulfilled obligations to hand over the relevant rules to the insured and they became obligatory for both parties to the contract. There must be a mark on the receiving of copy of insurance rules by the insured in insurance policy $^{28}$. Thus, among the insurer's duties it is reasonable to envisage not the obligation to inform the insured on the insurance conditions, by the insurer's duty to hand over a copy of the insurance rules to the insured as an integral part of the contract.

The main insurer's obligation under the insurance contract is making an insurance payment in a due period (insurance indemnity) stipulated by the contract upon occurrence of an insured event. The Law of Ukraine "On Insurance" distinguishes the concept of "insurance payment" and "insurance indemnity". The insurance payment is a monetary amount paid by the insurer in accordance with the insurance contract conditions at occurrence of an insured event. Insurance indemnity is an insurance payment made by the insurer within the limits of the insured amount under the contracts of property insurance and liability insurance upon the occurrence of an insured event.

The insurance payment (insurance indemnity) is considered to be the insurer's liability, but not a form of civil law liability. Property liability may be incurred by the insurer for late payment of insurance payments in the form of a penalty, the amount of which is determined by the contract terms and conditions. The attention should be paid to the fact that in case of an insured event occurrence under an insurance contract of civil liability, the insured can personally compensate for damages to the injured

\footnotetext{
${ }^{27}$ Цивільне право України. Особлива частина: підручник / За ред. О. В. Дзери, Н. С. Кузнєцової, Р. А. Майданика. 3-те вид., перероб. і доп. К.: Юрінком Інтер, 2010. С. 325.

${ }^{28}$ Кулина Ю. А. Договір страхування каско автотранспортних засобів у цивільному праві України: автореф. дис. ... канд. юрид. наук: 12.00.03; Нац. ун.-т «Одеська юридична академія». Одеса, 2013. С. 7.
} 
person, and then apply for compensation to the insurer who insured civil law liability.

Within two working days from the moment of receiving notice about occurrence of an insured event, the insurer must take measures for execution of all necessary documents for timely insurance payment (insurance indemnity) to the insured. Thus, in particular, in accordance with Part 3 of Article 13 of the Law of Ukraine "On the peculiarities of insurance of agricultural products with state support", the insurer is obliged within two working days, as soon as it becomes known about occurrence of an insured event, to take measures to execute all necessary documents for timely insurance payments and to draw up an insurance act, in which the following is noted: an evaluation of insured and uninsured risk impact on harvest; calculation method and data specified on the amount of losses; the size of the damaged area; the amount of losses incurred as a result of an insured event; additional expenses of the insured; calculation of insurance indemnity; parties' objections regarding the amount of the established damage. In case of partial damage to agricultural products, a preliminary evaluation of the damage caused as a result of occurrence of an insured event is carried out. After the end of a production cycle (agricultural year), the final evaluation of the damage is made and insurance indemnity is paid (Part 5, Article 13 of the Law of Ukraine "On the peculiarities of insurance of agricultural products with state support").

The insurer has the right to clarify the reasons and circumstances of an insured event. They can make the requests for information, connected with an insured event as well, to law enforcement authorities, banks, medical institutions and other organizations holding the information on insured event circumstances ${ }^{29}$. In return, these organizations are required to send responses to insurers for requests of information connected with an insured event, including data that is a commercial secret. In this case, the insurer is fully responsible for its disclosure, except for cases provided by law.

Upon submission of the application for payment and all necessary documents in accordance with the contract (rules of insurance), the insurer must consider the documents within the terms stipulated by the contract

${ }^{29}$ Цивільне право України: підручник: у 2-х т. / За ред. В. І. Борисової, І. В. Спасибо-Фатєєвої, В. Л. Яроцького. Харків: Право. 2011. Т. 2. С. 261. 
(rules of insurance) and take one of three decisions: on payment, on refusal to pay or on conducting an insurance investigation. The insurer and the insured have the right to involve, at their own expense, an emergency commissioner - a person who determines the causes of occurrence of an insured event and the amount of damage before investigation of insured event circumstances. In Ukraine the activities of emergency commissioners are regulated by the Decree of the Cabinet of Ministers of Ukraine "On Approval of the Model Regulations on Organization of Emergency Commissioner Activities" on January 5, $1998^{30}$.

According to the investigation results, the insurer recognizes the insured event occurrence, which is recorded in the insurance act (emergency certificate). According to Article 25 of the Law of Ukraine "On Insurance", insurance indemnity payment is made by the insurer in accordance with the insurance contract based on the statement of the insured (their successor or third parties) and the insurance certificate act (emergency certificate). The insurance act mentioned is made by the insurer or an authorized person (an emergency commissioner) in the form determined by the insurer (Article 990 of the Civil Code). In particular, according to Part 3, Article 13 of the Law of Ukraine "On the peculiarities of insurance of agricultural products with state support", an insurance act is made in two copies and signed by the insurer and the insured. The insurer can involve representatives of central executive authority in determination of the amount of damage and drawing up an insurance act, which ensures the state policy implementation in the field of supervision (control) in an agro-industrial complex, and/or central executive authority, which ensures the state policy implementation in the field of veterinary medicine. One copy of an insurance act remains with the insurer, the other - with the insured. In addition, when making an insurance act, the insurer and the insurer have the right to conduct an additional examination, appeal to any evidence documents to establish the causes and extent of damage. The cost of expertise is paid by the party requesting its conduct and is not included in the amount of insurance indemnity (Part 6, Article 13 of the Law of Ukraine "On the peculiarities of insurance of agricultural products with state support").

\footnotetext{
30 Типове положення про організацію діяльності аварійних комісарів, затверджене постановою Кабінету Міністрів України від 5 січня 1998 p. № 8. URL: http://zakon4.rada.gov.ua/laws/show/ 8-98-\%D0\%BF (дата звернення: 17.11.2018).
} 
Therefore, the insurer makes an insurance payment (insurance indemnity) based on the relevant condition stipulated in the insurance contract (voluntary insurance) or by law (compulsory insurance), as well as on the claim of the insured on occurrence of an insured event and an insurance act (emergency certificate) on the recognition by the insurer of the fact of insured event occurrence.

The occurrence of an insured event is not a definite ground for the insurance indemnity payment. The insurer has the right to refuse to pay the insurance indemnity in cases specified in Article 991 of the Civil Code and Article 26 of the Law of Ukraine "On Insurance". Relevant grounds can also be provided by the insurance contract, unless it contradicts with the law. The right to refuse to insurance payments means that, in the presence of a payment obligation, the insurer has the right to unilaterally refuse to comply with this obligation, but can fulfill it. As a rule, the list of grounds provided by the contract for insurer's refusal to insurance payment affects the value of insurance service, because insurance of the insured property interests with few grounds for refusal of the insurer to insurance payment is usually more expensive than insurance with a large number of grounds for such refusal.

By its nature, the insurer's refusal to pay insurance indemnity is a unilateral transaction, not requiring appeal to a court for non-performance of obligation to pay insurance indemnity ${ }^{31}$. The list of these grounds is not complete, as the law and the contract can be extended. At the same time, insurer's negative financial condition is not a ground for the refusal in insurance payment.

The grounds for insurer's refusal to insurance payments are as follows: a) intentional actions of the insured or a person in whose favor the insurance contract is made, aimed at the insured event occurrence; b) the commission of an insured citizen or other person in whose favor the insurance contract is made, an intentional crime that led to an insured event; c) the insured person's submission of knowingly false information about the insurance object or about the fact of the insured event occurrence; d) the insured person's untimely notification on the insured event occurrence without a legitimate reason or creation of an obstacle to the insurer in determining circumstances, nature and amount of damages;

\footnotetext{
${ }^{31}$ Соботник Р. В. Договір страхування цивільної відповідальності за шкоду, заподіяну джерелом підвищеної небезпеки: дис. ... канд. юрид. наук: 12.00.03. К., 2015. С. 90.
} 
e) the insured has previously received indemnity for property insurance from the person guilty of causing this damage; e) other cases stipulated by the legislation of Ukraine.

In general, the list of grounds provided by Article 26 of the Law of Ukraine "On Insurance" is not complete. The grounds for the insurer's refusal to make insurance payments can be other grounds determined by a lawmaker and stipulated by insurance contract conditions, for example, force majeure, military actions or other military events, terrorist act, mass disturbances, violations of public order, etc. In insurance practice, there are cases when insurers refuse to make insurance payments, referring to artificial (non-existent) grounds for violating the insurance contract conditions. However, the courts, establishing that the insured party duly fulfilled the insurance contract conditions: timely made insurance payments within the period established by the contract, timely informed the insurer of occurrence of the insured event, but the insurer, in violation of contractual obligations, did not make an insurance payment, satisfy the claim requirements for indemnification of the insurance payment amount $^{32}$.

The decision to refuse to make an insurance payment (insurance indemnity) is made by the insurer within the term not exceeding the term stipulated by rules of insurance, and the insured is informed in writing, with the justification of grounds for refusal. The insurer's refusal to pay the insurance indemnity may be appealed by the insured under the court procedure.

Unlike Article 991 of the Civil Code of Ukraine, providing grounds for insurer's refusal to the insurance payment, Article 266 of the Merchant Shipping Code of Ukraine stipulates the features of insurer's release from obligations under the contract. So, in case of insured event occurrence, the insurer has the right, by way of payment of the insurance full amount, to be released from further obligations under the maritime insurance contract. At the same time the insurer is obliged to notify the insured party about intention to use this right within seven days from the day of receiving from the insured the notification on insurance event occurrence

\footnotetext{
${ }^{32}$ Афанасьєв В. В., Погребняк В. Я., Янішен В. П., Бережна О. Д. Узагальнення судової практики вирішення господарськими судами спорів за участю страхових компаній (за матеріалами справ, розглянутих Харківським апеляційним господарським судом) // Актуальні питання цивільного та господарського права. 2013. № 5. С. 18-22; Постанова Харківського апеляційного господарського суду від 13.10.2008 p. у справі № 52/118-08 про стягнення страхового відшкодування. URL: https://register.dominus.kiev.ua/ (дата звернення: 18.10.2018).
} 
and its consequences, and, moreover, is obliged to indemnify the losses incurred by the insured party solely for the purpose of prevention or reduction of losses before receiving the insurer's notification.

The term of insurance payment (insurance indemnity) for a certain insured event is stipulated by the contract concluded by the parties. In case of compulsory insurance, this term is directly indicated in relevant rules of compulsory insurance. Thus, in case of making a decision on payment of insurance indemnity, the insurer, not later than fourteen working days from the date of receipt of documents, prepares an act and not later than three working days from the date of its compilation, pays the insurance indemnity (clause 12 of the Procedure and rules of carrying out of compulsory insurance of civil liability of economic entities for damage that may be caused by fires and accidents at objects of high danger, including fire and explosive dangerous objects and objects, economic activity on which can lead to accidents of ecological and sanitary-epidemiological nature $)^{33}$. In turn, the payment of insurance indemnity under the contract of compulsory insurance of civil liability for nuclear damage is carried out within the term not exceeding one month from the moment of the insured event occurrence (clause 3, Article 8 of the Law of Ukraine "On Civil Liability for Nuclear Damage and its Financial Provision" 34 ).

Article 1194 of the Civil Code of Ukraine states that a person, who insured own civil liability, in case of insufficiency of insurance indemnity for full indemnification of damage caused by them, is obliged to pay the difference between actual amount of damage and insurance indemnity to a victim.

The insurer is obliged to indemnify the expenses incurred by the insured during occurrence of an insured event in order to prevent or reduce losses, if it is provided by terms and conditions of the contract, and if measures taken by them were reasonable, regardless of their consequences, that is, regardless of whether they achieved the goal

\footnotetext{
${ }^{33}$ Порядок і правила проведення обов'язкового страхування цивільної відповідальності суб'єктів господарювання за шкоду, яка може бути заподіяна пожежами і аваріями на об'єктах підвищеної небезпеки, включаючи пожежо- і вибухонебезпечні об'єкти і об'єкти, господарська діяльність на яких може призвести до аварій екологічного і санітарно-епідеміологічного характеру, затверджені постановою Кабінету Міністрів України від 16 листопада 2002 р. № 1788. URL: http://zakon4.rada.gov.ua/laws/show/1788-2002-\%D0\%BF (дата звернення: 11.01.2019).

34 Закон України «Про цивільну відповідальність за ядерну шкоду та ії фінансове забезпечення» від 13 грудня 2001 р. // Відомості Верховної Ради України. 2002. № 14. Ст. 96.
} 
(whether the subject of insurance contract was rescued). Since such obligation of the insurer has a legal basis other than insurance indemnity, such expenses of the insured are subject to full compensation, in spite of the fact that in total with the insurance indemnity, they exceed the amount of damage caused ${ }^{35}$.

The insurer is primarily concerned in taking actions that prevent the insured event, since under contract conditions; the insurer is obliged to compensate for damage that will be caused. Therefore, the insurer should assist the insured party in taking actions aimed at reducing possible losses. Moreover, the insurer is obliged, upon the insured party's request, if the insurer takes measures reducing the insurance risk, to renew the insurance contract (Part 5, Article 988 of the Civil Code of Ukraine, Article 20 of the Law of Ukraine "On Insurance").

The insurer is obliged not to disclose information about the insured and their property status, except in cases established by law. In this case, it is about information that forms an insurance secret, such as something that can be classified as personal, family, official, commercial or other secret, which is the subject of legal protection. Thus, an insurance secret according to Article 40 of the Law of Ukraine "On Insurance" is confidential information about the activity and financial condition of the insured - the insurer's customer, which became known to the insurer during relations with a customer or third parties conducting activities in the field of insurance, disclosure of which may cause material or moral harm to the customer.

The insurer bears responsibility under the current legislation for disclosure of information obtained in connection with insurance activities about the insured, beneficiary, and the third party. Confidential information on the activities and financial situation of the insured may be provided only upon written request of the court, as well as law enforcement and tax authorities regarding the operations of insurance of a specific legal entity or natural person under a certain insurance contract in case of initiation of a criminal proceeding against this natural person or legal entity.

In order to protect the insurer's interests in property insurance (including liability insurance) Article 993 of the Civil Code of Ukraine

\footnotetext{
35 Цивільне право України: підручник: у 2-х т. / За ред. В. І. Борисової, І. В. Спасибо-Фатєєвої, В. Л. Яроцького. Харків: Право. 2011. Т. 2. С. 299.
} 
and Article 27 of the Law of Ukraine "On Insurance" establish a rule according to which the insurer who paid insurance indemnity obtains the right of claim within the limits of actual costs, which the insured or other person who received the insurance indemnity has to the person responsible for the damages incurred. The right to claim, which is transferred to the insurer, is limited to the amount of insurance indemnity paid to the insured (beneficiary) by the insurer. Therefore, the insurer acquires the right to claim only on condition of insurance indemnity payment within the limits of actual expenses. Losses not covered by the insurance indemnity payment may be collected by the insured (beneficiary) independently. Thus, if insurance indemnity payment does not fully compensate the damage caused to the insured (beneficiary) (for example, the contract provides for a deductible franchise), then two claims may be demanded from someone who caused damage: the first one is the insurer's claim in the amount of the insurance indemnity paid to the victim, the second on is the victim's claim in the amount of that part of harm caused, which was not covered by insurance indemnity. At the same time the lost benefits are not reimbursed here (except in case when lost benefits are insured by the contract individually), since in accordance with Article 988 the Civil Code of Ukraine the insurance payment under the property insurance contract can not exceed the amount of actual losses, while other losses are considered insured if it is expressly stipulated by the contract ${ }^{36}$.

Unfortunately, in practice, insurance companies often claim recourse in cases where a lawmaker provides the transfer of rights to the insurer under the subrogation procedure. Continuing the old tradition, insurers call such claims as regress claims, but not subrogation ones, and it does not correspond to the essence of legal relations arising in accordance with Article 993 of the Civil Code of Ukraine. Thus, the issue of differentiation the cases, when the law provides for the right of recourse, from the cases of subrogation, namely, the transfer of creditor's right, is extremely relevant.

It should be noted that in case of subrogation, there is only a change of persons in existing obligation (change of an active subject) with the preservation of obligation itself. Under recourse, one obligation changes

${ }^{36}$ Головачов Я. В. Суброгація у страхових правовідносинах: автореф. дис. ... канд. юрид. наук: 12.00.03. Одеса, 2017. С. 15. 
another one, but the transfer of rights from one creditor to another does not occur. Recourse in insurance arises in relation to a narrow circle of persons, and subrogation applies to any person responsible for the occurrence of an insured event. Moreover, subrogation enables the subjects to choose the time to exercise this right: for example, after payment of an insurance indemnity or during payment, as well as there are possible cases of subrogation use to the payment of insurance indemnity, that is, the insurer may file a lawsuit before the payment of an insurance indemnity to the court for the purpose of charging the caused harm from the victim in the part that the insurer must pay to the insured.

At subrogation, the insurer does not receive the right to indemnification for losses, but the right of claim, which the insured (beneficiary) has to the person responsible for the losses, compensated as a result of insurance. The limitation period for subrogation requirements should be calculated not from the moment of insurance indemnity payment, but from the moment of the insured event, since the change of creditor in obligation under the subrogation procedure occurs at the time of insurance indemnity payment, but the legal relations themselves between the insured and the actual party of damage - a person responsible for losses caused to the insured arise at the time of damage - an event that is an insurance event at the same time. In turn, as it is established in one of court cases by the Order of the Supreme Court of Ukraine on August 7, 2012, since according to Part 6, Article 261 of the Civil Code the limitation period for recourse proceeding begins from the day of the main obligation execution, then in this regard from the insurer's performance of own obligations under the contract of voluntary insurance, the insurer has the right to bring a recourse claim in the court ${ }^{37}$.

In some cases subrogation use is not possible. Thus, an insurance company in liability insurance can not replace the beneficiary in obligation in order to exercise the right to claim to the party guilty of causing harm, because this party is the insured party particularly. Therefore, in this case, the institution of recourse is used. However, there are cases when the courts, approving decisions according to rules of Article 993 of the Civil Code of Ukraine, at the same time refer to Article 38 of the Law of Ukraine "On Compulsory Insurance of Civil Liability of

37 Постанова Верховного Суду України від 7 серпня 2012 р. у справі № 3-31гс12. URL: http://zakon.rada.gov.ua/laws/show/n0005700-13 (дата звернення: 20.12.2018). 
Owners of Ground Transport Vehicles" which provides that the insurer who paid the insurance indemnity has the right to file a recourse action ${ }^{38}$. Nevertheless, as legal literature notes, in contrast to subrogation, in which the legal relations are preserved in a slightly modified form, recourse is another new legal relations ${ }^{39}$. In case of recourse the obligation fulfillment (by a debtor particularly or a third party) has as consequence of its termination and the payer receives the right to claim in a new obligation. In subrogation, on the contrary, the obligation is not terminated, and the payer takes the place of a creditor in existing legal relations $\mathrm{s}^{40}$.

So, the insurer takes a peculiar place in contractual insurance relations since it is with insurer's actions that the achievement of the main goal is connected, in favor of which such legal relations arise, - the payment of a certain sum in the amount and in cases provided by the contract.

In 2013, the European Commission Advisory Committee presented a report "On the results of research on current situation and perspectives of mutual insurance in Europe", containing proposals for expanding the activities of mutual companies and their mastering of new sectors in the field of insurance services ${ }^{41}$. It is worth noting that, at the Western European insurance market insurance cooperatives also operate along with mutual insurance societies, working on the principles of mutual assistance, solidarity, non-profitability as well. The identity of organizations mentioned is also confirmed by the creation of the Association of Mutual Insurers and Insurance Cooperatives in Europe (AMICE), emerged in 2008 on the basis of merger of the International Association of Mutual Insurance Companies (AISAM) and the Association of European Cooperatives and Mutual Insurance Companies $(\mathrm{ACME})^{42}$.

38 Постанова Верховного Суду України від 28 серпня 2012 р. у справі № 3-38гс12. URL: http://zakon.rada.gov.ua/laws/show/n0005700-13 (дата звернення: 21.12.2018).

39 Мартюк А. С. Загальна характеристика інституту регресних зобов'язань у цивільному праві України // Науковий вісник Херсонського державного університету. Серія: Юридичні науки. 2014. Вип. 6-1. Том 1. С. 178.

${ }^{40}$ Гриценко Г. Г. Множинність осіб у цивільно-правовому зобов'язанні: дис. ... канд. юрид. наук: 12.00.03. Харків, 2016. С. 120.

${ }^{41}$ European Parliament resolution of 14 March 2013 with recommendations to the Commission on the

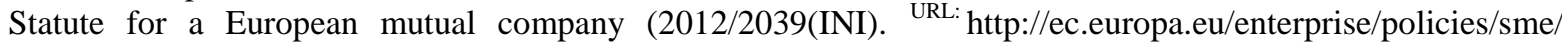
files/mutuals/prospects_mutuals_fin_en.pdf (Last accessed: 25.12.2018).

${ }^{42}$ Mutual Insurance in Figures: Executive summary from the 2010 study produced by AMICE's predecessor association, AISAM. Brussels: Association Internationale des Sociétés d'Assurance Mutuelle AISAM, 2010. 
The presence of a large number of non-profit insurance organizations in European countries is determined by the reasons relevant for the Ukrainian insurance market as well, namely: the necessity to obtain insurance services at economically reasonable prices by the insured persons, which is facilitated by the absence of a commercial component in relations between insurance participants; the democracy and transparency of activities of mutual insurance organizations, the control of which is exercised by its members; taking of specific risks on insurance, from which commercial insurance companies refuse, as a rule. At the same time, as "Strategy for development of the insurance market of Ukraine for 2012 - 2021" states, the national market problems are increasingly generated by unfair competition, insurance fraud, violation of insurance legislation, etc. ${ }^{43}$

For that reason Ukraine has a necessity in non-commercial insurance that will implement the principle of collective assistance of insurance participants. However, lack of gradual legal basis of mutual insurance companies' activity as well as similar practice of use, and above all, interpretation of normative acts creates a grave obstacle for their creation and proper functioning. Therefore, the procedure for creation, reorganization and winding up of a mutual insurance company should be detailed at the legislation level, the minimum number of members should be determined as well as their rights and obligations, voluntary admission and freedom to leave a company, grounds and conditions for termination of membership, and liability of members for insurance obligations. Moreover, national scholars justify the necessity of drafting and adopting the Law "On Mutual Insurance Companies" by the Verkhovna Rada of Ukraine, which will provide an opportunity to clearly identify the organizational, legal and economic foundations for their creation and activities $^{44}$. Mutual insurance as an alternative to commercial insurance

\footnotetext{
43 Стратегія розвитку страхового ринку України на 2012 - 2021 роки. URL: http://ufu.org.ua/ua/about/activities/strategic_initiatives/5257 (дата звернення: 28.12.2018) (Заголовок 3 екрану); Тимошенко I. В. Механізм функціонування товариств взаємного страхування і страхових кооперативів: перспективи розвитку в Україні // Науковий вісник Полтавського університету економіки і торгівлі. 2011. № 6 (51), ч. 2. Економіка, організація і управління підприємством. С. 177.

${ }^{44}$ Навроцький С. А. Страховий захист у сільському господарстві: теорія, методологія, практика: автореф. дис. ... док. екон. наук: 08.00.08; Нац. наук. центр «Інститут аграрної економіки УААН. К., 2012. 44 с.; Мачуський В. В. Правове регулювання страхової діяльності в Україні (господарсько-правові аспекти): автореф. дис. ... канд. юрид. наук: 12.00.04. К., 2013. 15 с.; Пацурія Н. Б. Страхові правовідносини у сфері господарювання: проблеми теорії і практики: монографія. Ніжин: ТОВ «Видавництво «Аспект-Поліграф», 2013. 504 с.
} 
provided by law should help in facilitation of real insurance protection of the insured (natural persons and legal entities) and provide them with quality insurance services.

\section{Information about the author: \\ Milovska N. V.}

Candidate of Juridical Sciences, Assistant Professor at the Department of Special Legal Disciplines of the V. I. Vernadsky Taurida National University 